\title{
PENGARUH CARBOXYMETHYL CELULOSA NATRIUM SEBAGAI PENGENTAL TERHADAP STABILITAS SIRUP TEMULAWAK (CURCUMA XANTHORRIZA ROXB)
}

\author{
Nutrisia Aquariushinta Sayuti \\ Kementerian Kesehatan, Politeknik Kesehatan Surakarta, Jurusan Jamu
}

\begin{abstract}
Carboxymethyl celulosa natrium, Curcuma xanthorriza Roxb syrup, Stability. The lack flavor and amylum contain of Curcuma xanthorriza Roxb cause difficulty to make it in to syrup. Carboxymethyl Celulose Natrium (CMC$\mathrm{Na}$ ) as a thickener was needed to solve the problem. The study aim to determine the influence of CMC-Na to syrup's stability Curcuma xanthorriza. The methode was used to determine stability of syrup formulation with three formula with variations in the amount of $1 \%$ CMC-Na solution and $80 \%$ sucrose solution. Physical stability parameter of the syrup such as viscosity, acidity and organoleptic analyzed by two way anava. The result showed that $\mathrm{CMC}-\mathrm{Na}$ effected on viscosity, acidity and organoleptic of the syrup. There are influence of CMC-Na to syrup's stability.
\end{abstract}

Keyword: Carboxymethyl celulosa natrium, Curcuma xanthorriza Roxb syrup, Stability

Abstrak : Carboxymethyl celulosa natrium, Temulawak sirup, Stabilitas. Rasa yang tidak enak dan kandungan amylum dalam temulawak (Curcuma xanthorriza Roxb) menyulitkan dalam pembuatan sirup temulawak. Carboxymethyl Celulose Natrium (CMC-Na) sebagai pengental diperlukan untuk mengatasi masalah tersebut. Tujuan penelitian ini adalah untuk mengetahui pengaruh $\mathrm{CMC}-\mathrm{Na}$ terhadap stabilitas sirup temulawak. Metode dipergunakan untuk mengetahui stabilitas dari tiga formula sirup temulawak dengan konsentrasi larutan CMC-Na $1 \%$ dan larutan sucrosa $80 \%$ yang berbeda. Parameter stabilitas fisik dari sirup yang terdiri dari viskositas, derajat keasaman dan organoleptic dianalisis dengan anava dua arah. Hasil penelitian menunjukkan bahwa CMC-Na berpengaruh pada kekentalan, derajat keasaman dan organoleptis sirup. CMC-Na berpengaruh terhadap stabilitas sirup.

Kata Kunci: Carboxymethyl celulosa natrium, Sirup temulawak, Stabilitas.

\section{PENDAHULUAN}

Temulawak

(Curcuma

xanthorriza Roxb.) merupakan salah satu simplisia yang tidak pernah ditinggalkan dalam pembuatan jamu. Hal tersebut disebabkan oleh kandungan kurkumin dalam temulawak yang dari segi ilmiah dapat merangsang sekresi empedu mau pun menangkal radikal bebas sehingga dapat meminimalisir efek negatif dari simplisia lain yang dikombinasikan bersama temulawak (Puspitojati dan Santoso, 2012; Rachman et al, 2008).

Rasa pahit dan kandungan pati dalam temulawak seringkali menyulitkan dalam memformulasikan simplisia ini dalam sediaan sirup. Hal 
ini dikeluhkan oleh beberapa pengusaha jamu di daerah Sukoharjo, Jawa Tengah. Salah satu cara menghilangkan rasa pahit dalam sirup bisa ditambahkan asam jawa, akan tetapi pati dalam temulawak terkadang masih menyisakan endapan di dasar botol walau pun penyaringan sudah dilakukan di akhir pembuatan sirup. Hal ini menyebabkan berkurangnya penerimaan konsumen terhadap sediaan sirup yang dihasilkan. Bahan pengental yang dapat ditambahkan pada sediaan tersebut adalah Carboxymethyl celulosa natrium (CMC-Na). CMC-Na dapat mensuspensikan pati dalam sirup temulawak sehingga diharapkan endapan tidak terjadi. Penelitian ini bertujuan untuk mengetahui pengaruh CMC-Na sebagai pengental terhadap kestabilan sirup temulawak. Stabilitas sirup diuji dengan penyimpanan selama 4 minggu dengan pengujian setiap minggu.

\section{METODE PENELITIAN}

Penelitian ini adalah penelitian eksperimental. Simplisia temulawak dan daging buah asam jawa dengan perbandingan berat 800 banding 1 diambil sarinya secara infundasi. Perbandingan antara simplisia temulawak dengan air yang digunakan adalah 1 banding 4. Cairan infusa dibagi dua untuk membuat larutan sucrosa $80 \%$ dan larutan CMC-Na $1 \%$. Formula dapat dilihat pada tabel 1 . Pengujian stabilitas dilakukan dengan menyimpan sediaan sirup selama 4 minggu dan diuji viskositas, derajat keasaman $(\mathrm{pH})$ dan organoleptik sirup. Analisa hasil dilakukan dengan analisa bivariat.
Tabel 1

\section{Formula sirup temulawak}

\begin{tabular}{|c|c|c|c|}
\hline Bahan & $\begin{array}{l}\text { Formula } \\
\text { I }\end{array}$ & $\begin{array}{c}\text { Formula } \\
\text { II }\end{array}$ & $\begin{array}{c}\text { Formula } \\
\text { III }\end{array}$ \\
\hline $\begin{array}{l}\text { Sucrosa } \\
80 \%\end{array}$ & 0 & 50 & 25 \\
\hline $\begin{array}{l}\text { CMC-Na } \\
1 \%\end{array}$ & 50 & 0 & 25 \\
\hline Asam Sitrat & 3 & 3 & 3 \\
\hline Madu & 5 & 5 & 5 \\
\hline $\mathrm{Na}$ Benzoat & 0,06 & 0,06 & 0,06 \\
\hline $\begin{array}{l}\text { Infusa } \\
\text { Temulawak } \\
\text { sampai }\end{array}$ & $60 \mathrm{ml}$ & $60 \mathrm{ml}$ & $60 \mathrm{ml}$ \\
\hline \multicolumn{4}{|c|}{$\begin{array}{l}\text { Keterangan : } \\
\text { Formula I }=100 \% \text { CMC-Na } \\
\text { Formula II }=100 \% \text { Sukrosa } \\
\text { Formula III }=50 \% \text { CMC-Na dan } 50 \% \text { Sukrosa }\end{array}$} \\
\hline
\end{tabular}

\section{HASIL PENELITIAN}

Hasil penelitian menunjukkan bahwa CMC-Na berpengaruh pada kekentalan, derajat keasaman dan organoleptis sirup. CMC-Na berpengaruh terhadap stabilitas sirup

\section{PEMBAHASAN}

Dalam penelitian, peneliti membandingkan stabilitas 3 formula sirup dimana sirup formula II adalah resep asli yang sudah diproduksi oleh beberapa pengusaha jamu di daerah Sukoharjo, formula I formula sirup tanpa gula sedangkan formula III adalah kombinasi dari sukrosa dan CMC-Na. Formula tersebut adalah formula sirup yang pemakaiannya harus dicampurkan dengan air secukupnya terlebih dahulu untuk dapat dikonsumsi. Masing-masing formula dibuat $60 \mathrm{ml}$ dengan replikasi 3 kali. Hasil dari formula dilakukan uji stabilitas dengan cara pengamatan viskositas, $\mathrm{pH}$ dan organoleptik. Pengamatan dilakukan setiap minggu selama 4 minggu dalam suhu kamar. 


\begin{tabular}{cccccc}
\hline Formulasi & \multicolumn{5}{c}{ Viskositas (mPas) } \\
\cline { 2 - 6 } & Minggu & Minggu & Minggu & Minggu & Minggu \\
& 0 & 1 & 2 & 3 & 4 \\
\hline Formula & 149,33 & 131,67 & 131,67 & 132,67 & 133,67 \\
I & \pm & \pm & \pm & \pm & \pm \\
& 0,57 & 1,53 & 1,53 & 1,53 & 1,53 \\
\hline Formula II & 121,00 & 122,33 & 110,33 & 101,33 & 99,00 \\
& \pm & \pm & \pm & \pm & \pm \\
& 1,00 & 1,53 & 1,53 & 1,21 & 1,01 \\
\hline Formula III & 129,00 & 120,67 & 121,00 & 114,00 & 103,67 \\
& \pm & \pm & \pm & \pm & \pm \\
& 0,99 & 0,56 & 0,58 & 0,39 & 0,07 \\
\hline
\end{tabular}

Tabel 2

Hasil Viskositas Formulasi Sirup Temulawak

Keterangan $: \mathrm{a} \pm \mathrm{b}=$ purata $\pm \mathrm{SD}$

, $\mathrm{n}=3$

Viskositas sirup menurut tabel 2 memiliki kecenderungan menurun dari minggu ke minggu. Viskositas sirup berkaitan dengan konsentrasi CMC-Na dalam sirup. Semakin tinggi konsentrasi CMC-Na semakin tinggi pula viskositas sirup yang dihasilkan. CMC-Na mudah larut dalam air panas maupun air dingin. Pengurangan viskositas dapat terjadi pada saat pemanasan yang bersifat dapat balik (reversible). Saat Na-CMC dimasukkan ke dalam air, $\mathrm{Na}+$ lepas dan diganti dengan ion $\mathrm{H}+$ dan membentuk HCMC yang akan meningkatkan viskositas (Bochek et al., 2002). Kemasan yang kurang kedap juga dapat menurunkan viskositas karena dapat menyebabkan sirup menyerap uap air dari luar, sehingga menambah volume air dalam sirup (Panjaitan dan Saragih, 2012).

Analisa statistik anava dua arah pada viskositas ketiga formula pada tingkat kepercayaan 95\% menunjukkan $p$ value $0,00 \quad(<0,05)$ sehingga dapat disimpulkan bahwa terdapat perbedaan terhadap viskositas ketiga formula yang diujikan. Uji Tuckey menjukkan terdapat perbedaan viskositas antara ketiga formula. Dari analisis ini dapat disimpulkan bahwa
CMC-Na berpengaruh pada stabilitas viskositas sirup.

Menurut Murukmihadi, 2011, penurunan viskositas sirup kemungkinan juga disebabkan oleh teroksidasinya CMC-Na akibat pengaruh udara. Kerusakan sistem dispersi koloid CMC-Na akibat molekul oksigen udara terjadi dengan putusnya gugul karboksil sehingga viskositas sirup menurun (Hoefler, A.C., 2004, Murukmihadi, dkk, 2011 ). Hal inilah yang menyebabkan viscsitas sirup cenderung mengalami penurunan.

\section{Tabel 3}

\section{Hasil pH Formulasi Sirup} Temulawak

\begin{tabular}{cccccc}
\hline Formulasi & \multicolumn{5}{c}{$\mathrm{pH}$} \\
& \multicolumn{7}{c}{ Minggu } & Minggu & Minggu & Minggu & Minggu \\
& 0 & 1 & 2 & 3 & 4 \\
\hline Formula & 3,76 & 3,77 & 3,76 & 3,56 & 3,33 \\
I & \pm & \pm & \pm & \pm & \pm \\
& 0,03 & 0,15 & 0,11 & 0,03 & 0,01 \\
\hline Formula & 3,91 & 3,78 & 3,62 & 3,45 & 3,02 \\
II & \pm & \pm & \pm & \pm & \pm \\
& 0,13 & 0,01 & 0,03 & 0,09 & 0,02 \\
\hline Formula & 3,41 & 3,29 & 3,32 & 3,29 & 3,20 \\
III & \pm & \pm & \pm & \pm & \pm \\
& 0,93 & 0,11 & 0,67 & 0,74 & 0,08 \\
\hline
\end{tabular}

Keterangan $: \mathrm{a} \pm \mathrm{b}=$ purata $\pm \mathrm{SD}$

$$
, \mathrm{n}=3
$$

PH sirup menurut tabel 3 memiliki kecenderungan menurun dari minggu ke minggu. Uji anava dua arah menunjukkan $p$ value 0,00 sehingga dapat disimpulkan bahwa terdapat perbedaan bermaka antara derajat keasaman ketiga formula sirup. Tuckey test menunjukkan bahwa ada perbedaan antara satu formula dengan formula lain sehingga dapat disimpulkan bahwa CMC-Na berpengaruh terhadap stabilitas $\mathrm{pH}$ sirup.

Viskositas larutan CMC-Na dipengaruhi oleh $\mathrm{pH}$ larutan, kisaran pH CMC-Na adalah 5-11 sedangkan $\mathrm{pH}$ optimum adalah 5, dan jika $\mathrm{pH}$ terlalu rendah $(<3)$, CMC-Na akan mengendap (Tranggono, dkk, 1991). 
CMC-Na mudah larut dalam air panas maupun air dingin. Pada pemanasan dapat terjadi pengurangan viskositas yang bersifat dapat balik (reversible). Viskositas larutan CMC-Na dipengaruhi oleh $\mathrm{pH}$ larutan, kisaran pH CMC-Na adalah 5-11 sedangkan $\mathrm{pH}$ optimum adalah 5 , dan jika $\mathrm{pH}$ terlalu rendah $(<3)$, CMC-Na akan mengendap (Tranggono, dkk, 1991).

Uji organoleptik meliputi pengamatan warna, bau, rasa dan tekstur pada sirup temulawak dengan menggunakan panca indera. Hasil uji organoleptik terhadap sirup temulawak formula I, II dan III selama penyimpanan 4 minggu relatif stabil yaitu beraroma temulawak, rasa, warna kuning kecoklatan, tekstur agak kental akan tetapi pada formula II terdapat sedikit endapan yang mengharuskan sirup dikocok dulu sebelum digunakan. Hal ini disebabkan viskositas sirup formula II tidak cukup menahan endapan serbuk. Kesan tanpa endapan ini lebih disukai oleh konsumen. Hal ini sesuai dengan hasil penelitian Anis Marfuah dan Sutaryono tentang CMC sebagai suspending agent terhadap stabilitas fisik suspensi Kloramfenikol, yang menyatakan bahwa suspensi yang mengalami flokulasi mengalami proses sedimentasi terhambat. Pada partikel tunggal yang bersentuhan kemudian menyatu menjadi flokulat bergerak turun, berasosiasi tidak hanya dengan partikel flokulat berikutnya tetapi juga dengan partikel tunggal yang sangat halus, cairan yang terbentuk adalah jernih (Voight, 1994).

Rasa pahit dan getir dari temulawak sudah dapat ditutupi dengan rasa manis pada sirup formula I dan III sedangkan pada formula II masih didapatkan rasa getir, hal ini disebabkan rasa manis madu yang digunakan tidak mencukupi untuk menutupi rasa tidak enak tersebut walau pun rasa asam jawa memberikan kesan segar ketika diminum.

\section{KESIMPULAN DAN SARAN}

Gambaran stabilitas fisik sirup temulawak adalah viskositas setiap formula cenderung menurun diiringi dengan penurunan $\mathrm{pH}$ sirup. Sirup formula yang tidak mengandung CMC$\mathrm{Na}$ tidak mampu mendispersikan zat pati dari temulawak sehingga masih terdapat endapan. Kesimpulan dari penelitian ini adalah penambahan CMC-Na berpengaruh pada stabilitas sediaan sirup temulawak.

\section{DAFTAR RUJUKAN}

Bochek, A.M., Yusupova, L.D., Zabivalova, N.M., Petropavlovskii, G.A. 2002. Rheological Properties of Aqueous H-Carboxymethyl Cellulose Solutions with Various Additives.Russian Journal of Applied Chemistry.75: 4-7.

Hoefler, A.C., 2004, Sodium Carboximethyl Cellulose, Chemistry, Functionality, and Applications, http://www.herc.com/foodgums /index.htm, 22 Juni 2010.

Murukmihadi, Wahyuono, Marchaban, Martono, 2011. Optimasi Formulasi Sirup Fraksi tidak Larut Etil Asetat Yang Mengandung Alkaloid dari Bunga Kembang Sepatu (Hibiscus rosa-sinensis L.), Jurnal, Jogjakarta : Majalah Obat Tradisional 16(2) 101 108.

Panjaitan, E. N., A. Saragih, dan D. Purba. 2012. Formulasi Gel dari Ekstrak Rimpang Jahe Merah 
13 Jurnal Kebidanan Dan Kesehatan Tradisional, Volume 1, No 1, Maret 2016, hlm 1-99

(Zingiber officinale Roscoe).

Journal of Pharmaceutics and

Pharmacology. 1(1): 9-20.

Universitas Sumatera Utara:

Jurusan Farmasi

Puspitojati, E dan Santoso, H. 2012.

Optimasi Fermentasi pada

Pembuatan Ekstrak Temulawak

Sebagai Bahan Baku Es Krim.

Jurnal ilmu-ilmu pertanian

volume 16, No. 2 , Desember

2012. Surakarta: Jurusan

pertanian.

Rachman, 2008, Aktivitas antioksidan

Ekstrak Tunggal dan

Kombinasinya dari Tanaman

Curcuma sp. Jurnal, Ilmu

Kefarmasian Indonesia, vol 6

No.2, 69-74.

Tranggono, IR , Latifah, 2007, Buku

Pegangan Ilmu Pengetahuan

Kosmetika, Jakarta, PT.

Gramedia Pustaka Utama

Voight, 1994, Buku Pelajaran

Teknologi Farmasi, Terjemahan

Soendani, Edisi V, Jogjakarta, Universitas Gadjah Mada, 572537. 